\title{
Z Kuşağının Tüketim Değerleri: Cep Telefonu Ürünü Üzerinden Nitel Bir Araştırma1 (Consumption Values of Z Generation: A Qualitative Research on Mobile Phone Product)
}

\author{
Şemsettin Ozan ÇELEBI iD a Funda BAYRAKDAROĞLU iD b \\ a Muğla Sıtkı Koçman Üniversitesi, Sosyal Bilimler Enstitüsü, İşletme Anabilim Dall, Muğla, Türkiye. s.ozancelebi@gmail.com \\ b Muğla Sıtkı Koçman Üniversitesi, İktisadi ve İdari Bilimler Fakültesi, İşletme Bölümü, Muğla, Türkiye. fkaya@mu.edu.tr
}

\begin{tabular}{|c|c|}
\hline MAKALE BİLGİSİ & ÖZET \\
\hline $\begin{array}{l}\text { Anahtar Kelimeler: } \\
\text { Tüketim Değerleri } \\
\text { Kuşaklar } \\
\text { Z Kuşağ }\end{array}$ & $\begin{array}{l}\text { Amaç - Büyük oranda gelişmiş teknolojinin etkisiyle yaşamları şekillenen Z Kuşağının günümüz } \\
\text { dünyasındaki satın alma davranışlarını anlamlandırmak önemli bir konu başlığıdır. Tüketicilerin } \\
\text { hangi sebeplerle satın aldıklarını belirlemek adına kullanılan tüketim değerleri teorisi, tüketiciler } \\
\text { tarafından ürün ve hizmetlere atfedilen değerler hakkında bilgi sağlamaya yardımcı olmaktadır. } \\
\text { Buradan hareketle çalışmanın amacı Z Kuşağının tüketim değerlerini cep telefonu özelinde ortaya } \\
\text { koyabilmektir. }\end{array}$ \\
\hline $\begin{array}{l}\text { Gönderilme Tarihi } 13 \text { Temmuz } \\
2020 \\
\text { Revizyon Tarihi } 10 \text { Eylül } 2020 \\
\text { Kabul Tarihi } 18 \text { Eylül } 2020\end{array}$ & $\begin{array}{l}\text { Yöntem - Nitel araştırma temelinde gerçekleştirilen bu çalışmanın örneklemini Muğla'nın Menteşe } \\
\text { ilçesinde yaşayan Z Kuşağı bireyleri oluşturmaktadır. Araştırma verileri görüşme (mülakat) } \\
\text { yöntemi ile toplanmış olup, veri toplama aracı olarak yarı yapılandırılmış görüşme formu } \\
\text { kullanılmıştır. Yapılan görüşmeler sonunda elde edilen verilerin çözümlenmesinde betimsel analiz } \\
\text { tekniğinden faydalanılmıştır. }\end{array}$ \\
\hline & $\begin{array}{l}\text { Bulgular - Araştırma bulgularına göre Z Kuşağı tüketicileri cep telefonu satın alma tercihlerinde } \\
\text { başta fonksiyonel değer olmak üzere yenilik değeri ve durumsal değeri ön planda tutmaktadır. } \\
\text { Duygusal değerin satın alma tercihlerinde kısmen fonksiyonel değere bağlı olarak anlam kazandığı, } \\
\text { sosyal değerin ise oldukça düşük bir etkiye sahip olduğu görülmektedir. }\end{array}$ \\
\hline Araştırma Makalesi & $\begin{array}{l}\text { Tartışma - Tüketim değerleri ile alakalı elde edilen bulguların büyük bir kısmının Z Kuşağının satın } \\
\text { alma davranışları ile ilgili literatürü desteklediği görülmektedir. Araştırma sonucuna göre özellikle } \\
\text { fonksiyonel ve yenilik değerinin yüksek olması nedeniyle, şirketlerin öncelikli olarak bu değerlere } \\
\text { odaklanmasının, Z Kuşağının tüketim tercihlerine ilişkin en güçlü yatırım olacağı söylenebilir. }\end{array}$ \\
\hline
\end{tabular}

\begin{tabular}{|c|c|}
\hline ARTICLE INFO & ABSTRACT \\
\hline $\begin{array}{l}\text { Keywords: } \\
\text { Consumption Values } \\
\text { Generations } \\
\text { Z Generation }\end{array}$ & $\begin{array}{l}\text { Purpose - It is an important topic to make sense of the purchasing behavior of Generation } \mathrm{Z} \text {, whose } \\
\text { lives are largely shaped by the influence of advanced technology. The consumption values theory } \\
\text { used to determine for what reasons consumers buy helps to provide information about the values } \\
\text { attributed by consumers to products and services. From this point of view, the aim of the study is to } \\
\text { reveal the consumption values of Generation } Z \text { specific to mobile phones. }\end{array}$ \\
\hline $\begin{array}{l}\text { Received } 13 \text { July } 2020 \\
\text { Revised } 10 \text { September } 2020\end{array}$ & $\begin{array}{l}\text { Design/methodology/approach - The sample of this study, which is carried out on the basis of } \\
\text { qualitative research, consists of } Z \text { Generation individuals living in Menteşe district of Mughla. The } \\
\text { research data were collected by interview method and semi-structured interview form was used as } \\
\text { data collection tool. Descriptive analysis technique was used to analyze the data obtained from the } \\
\text { interviews. }\end{array}$ \\
\hline Accepted 18 September 2020 & $\begin{array}{l}\text { Findings - According to the research findings, Generation } \mathrm{Z} \text { prioritizes especially functional value, } \\
\text { innovation value and situational value in mobile phone purchase preferences. It is seen that } \\
\text { emotional value gains meaning partially depending on functional value and social value has a very } \\
\text { low effect in purchasing preferences. }\end{array}$ \\
\hline Research Article & $\begin{array}{l}\text { Discussion - It is seen that most of the findings related to consumption values support the literature } \\
\text { on Generation Z's buying behavior. According to the results of the research, it can be said that the } \\
\text { focus of companies on these values will be the strongest investment regarding the consumption } \\
\text { preferences of the Generation } Z \text {, since the functional and innovation value is significant. }\end{array}$ \\
\hline
\end{tabular}

${ }^{1} \mathrm{Bu}$ çalışma, Şemsettin Ozan ÇELEBİ'nin Muğla Sıtkı Koçman Üniversitesi Sosyal Bilimler Enstitüsü İşletme Anabilim Dalında tamamlanan Yüksek Lisans tezinden üretilmiştir.

\section{Önerilen Atıf/Suggested Citation}

Çelebi, Ş., O., Bayrakdaroğlu, F. (2020) Z Kuşağının Tüketim Değerleri: Cep Telefonu Ürünü Üzerinden Nitel Bir Araştırma, İşletme Araştırmaları Dergisi, 12 (3), 3055-3070. 


\section{Giriş}

Belirli zamanlarda meydana gelen başta teknolojik olmak üzere sosyal, ideolojik, ekonomik, politik veya bilimsel değişimler insanların kişilik ve davranışlarını etkilediği gibi tüketim olgusuna da doğrudan etkide bulunmaktadır. Satın alma ve tüketim davranışları, Odabaşı ve Barış'ın (2007) da belirttiği üzere insanların ortaya çıkardığı bir değer vasıtasıyla gerçekleştiğinden tüm bu değişkenlerin tüketim eylemine konu olan ürün veya hizmetlere yansıması ve tüketimdeki değer boyutlarını etkilemesi de olağan bir durum olarak karşımıza çıkmaktadır. İşletmeler, tüketicileri etkilemek için pazarlama programlarını bu değerler üzerine şekillendirerek, pazara sundukları ürün veya hizmetler ile tüketicilerin istek ve ihtiyaçlarını karşılayabilirler ancak kuşak olarak nitelendirilen ve doğdukları yılların içinde bulundukları mevcut şartlarından etkilenip, benzer birtakım özellikler gösteren insanların bağımsız karakteristik özellikleri ve tüketim tercihlerinin olduğu da unutulmamalıdır. Bu çerçevede, farklı kuşaklara ait insanların tüketimlerinde ortaya çıkardıkları değerlerin de birbirinden farklılık göstereceğinden yola çıkarak teknoloji ve dijital çağın en ihtişamlı dönemlerinde dünyaya gelen Z Kuşağının tüketim değerlerini anlamlandırmak çalışmanın temel amacını oluşturmaktadır. Günümüz genç nüfusunun büyük çoğunluğunu oluşturan $Z$ Kuşağ1 tüketicilerine ait tüketim değerlerinin incelenmesinin yanı sıra elde edilen bilgiler ışığında işletmelerin, hedef kuşağa yönelik ürün/hizmet planlamasına katkı sağlayacağı düşüncesi de araştırmanın diğer bir amacına hizmet etmektedir. Güncelliğini koruyan tüketim değerleri konusu üzerine dünya literatüründe birçok çalışma bulunmasına rağmen, Türkçe literatürde tüketim değerleri konusuna yönelik araştırmaların oldukça sınırlı olduğu; Z Kuşağının tüketim değerlerinin belirlenmesine yönelik ise bir çalışma yürütülmediği görülmektedir. Bu çalışma ile literatürdeki söz konusu boşluğun doldurulması hedeflenmektedir.

\section{Kuşak Kavramı ve Z Kuşağı}

Kuşak kavramı ile ilgili ilk bilimsel araştırmalar ünlü Fransız sosyolog ve filozof Auguste Comte tarafından 1830 ile 1840 yılları arasında gerçekleştirilmiştir (Latif ve Serbest, 2014: 136). Günümüze daha yakın zamanlarda ise kuşak kavramına popülerlik kazandıran Strauss ve Howe, çoğunlukla Strauss-Howe Teorisi (1991) olarak bilinen Kuşak Teorisi'ni geliştirmiştir. O zamandan günümüze kadar bu kavram sosyal bilimlerde özellikle yönetim, insan kaynakları ve pazarlama gibi bilim dallarında yaygın olarak kullanılmaktadır (Chaney vd., 2017: 179).

Altuntuğ (2012) kuşakları “aynı zaman aralığında doğmuş, yaşadıkları zamanın sosyal, ekonomik, kültürel, siyasal olaylarından ve hâkim değerlerinden etkilenmiş kişileri ve bu kişilerin oluşturdukları toplulukları" (s.204) şeklinde ifade etmektedir. Williams ve Page (2011) ise kuşakları "bir arada yaşayan benzer yaşlarda benzer olaylar yaşayanlar, yani ortak bir sosyal, siyasi, tarihsel ve ekonomik ortamı paylaşan bireyler" (s.2) olarak tanımlamaktadır. Kısacası kuşaklar ile ilgili, sınırları belirli zaman dilimleri içerisinde doğan, yaşadıkları toplumsal olayların sonucu olarak birbirine yakın davranışlar sergileyen, benzer bakış açılarına sahip insan toplulukları şeklinde genel bir tanımlama yapılabilir.

Buradan hareketle, kuşakların bakış açılarını ortaya koyabilmek adına kuşak sınıflandırılmaları yapılması zorunluluk halini almıştır. Literatürde kuşakların Sessiz Kuşak, Bebek Patlaması Kuşağı, X Kuşağı, Y Kuşağı, $Z$ Kuşağı ve Alfa Kuşağı şeklinde adlandırıldığı; ancak geçmiş araştırmalar incelendiğinde bahsi geçen kuşakların tarih aralıklarına ilişkin bir fikir birliği bulunmadığı görülmektedir. Literatürde Z Kuşağı tarih aralıkları önemli ölçüde değiş̧iklik göstermesine rağmen (Dolot, 2018), yabancı literatürde 1995-2010 (Williams ve Page, 2011; Andrea vd., 2016; Bejtkovský, 2016; Patel, 2017; Francis ve Hoefel, 2018) tarihsel sinırlamasının öne çıktığı söylenebilir. Fakat yabancı literatürde belirtilen tarih aralıklarının çoğunun ülkemiz koşulları ile tam anlamıyla bağdaşmayacağı düşünülmektedir. Bu nedenle, Türkiye için kuşak sınıflandırmalarında; 19251945 arası yıllar için Sessiz Kuşak ya da Geleneksel Kuşak, 1946-1964 yılları için Bebek Patlaması Kuşağı, 19651979 yılları arası için X Kuşağı, 1980-1999 yılları için Y Kuşağı, 2000 ve sonrası için M Kuşağı ya da Z Kuşağ1 aralıkları daha anlamlıdır (Demir vd., 2017: 82).

2000 ve sonrasında dünyaya gelen kişileri ifade eden Z Kuşağı, sosyal hayatlarını dijital merkezli dünya ve teknoloji ile birleştirmiş olan bireylerden oluşmaktadır (Tuncer, 2016: 34). Yaşam standartlarında meydana gelen değişim ve dönüşümler $Z$ Kuşağının diğer kuşaklara kıyasla bambaşka bir dünyada yetişmelerine sebep olmuştur. Özellikle teknoloji temelli ilerlemeler Z Kuşağının karakteristik özelliklerini diğer kuşaklardan ayrıştırmıştır (Erden Ayhün, 2013: 102). Tekno-küresel bir dönemde dünyaya gelen Z Kuşağı bireyleri dünyanın herhangi bir yerindeki herhangi bir kişiyle iletişim kurabilmekte ve bilgi paylaşımı 
yapabilmektedir. Teknoloji bağımlısı olarak adlandırılabilecek Z Kuşağı teknolojiye tam anlamıyla hâkim, internet tabanlı oyunlar oynayan, sosyalleşmeyi dijital mecrada gerçekleştiren, $7 / 24$ çevrimiçi olan, internetten bilgi toplayan ve sürekli bir şeyler paylaşan bir kuşaktır. İhtiyaç duyduğu tüm bilgilere yine internet aracılığıyla ulaşabilen Z Kuşağı, tüm kuşaklar arasında internetle en çok bağlantı halinde olan kuşak olduğu düşünülmektedir (Berkup, 2014: 224). Z Kuşağ1 bireyleri zamanlarının büyük bir kısmını çevrimiçi geçirdiğinden arkadaşlıklarını genellikle sosyal medya üzerinde inşa etmektedirler. Dünyaları dijital bir ortam olduğu için karakterleri de sanal bir ortam gibi şekillenmektedir (Özkan ve Solmaz, 2017: 151). Z Kuşağ1 bireyleri temelde hız kavramının ön planda olduğu bir zamanda dünyaya geldiğinden, hıza dair şeyleri sevmekte ve arzulamaktadırlar. İletişimden yemeğe kadar her şeyin hızlı olmasını istemektedirler (Arar ve Yüksel, 2015: 48).

Z Kuşağı, tüketimden etkilenmelerinin yanı sıra tüketim trendlerini de etkileyen bir profile sahiptir. Z Kuşağ1 tüketicileri her konuda kişiselleştirilmiş, kendine has ve imaja dayanan bir tüketim tarzını yansıtmaktadır. Önceki kuşaklara kıyasla eğitim ve ekonomik açıdan daha donanımlılardır. Kuşağın bireyleri istedikleri her ürüne hemen sahip olmak, hemen tüketmek ve sonrasında yeni tüketim deneyimlerine yönelmeyi arzu etmektedirler (Altuntuğ, 2012: 204-209). Z Kuşağının bulunduğu pazar segmenti bugüne kadarki en eğitimli, mobil ve internete bağlı kişilerin bulunduğu tüketici grubunu kapsamaktadır. Bu tüketiciler aynı zamanda sosyal anlamda bilinçli, teknolojiye duyarlı, yenilikçilik başta olmak üzere kalıcı değişimler aramaktadır (Chaney vd., 2017: 182).

\section{Tüketim Değerleri}

Pazarlama araştırmalarının çok büyük bir kısmı tüketicilerin satın alma kararlarını nasıl aldıklarını anlama ve öngörme üzerine yoğunlaşmıştır (Gabbott ve Hogg, 1998: 6). Modern yaklaşımlarda çoğunlukla tüketici için değerli olanı bulabilmek ve tüketiciye değer sunabilmek, değer verebilmek üzerinde durulmaktadır. Ancak tüketicilere hangi tür değer ile yaklaşılması gerektiği konusu önem teşkil etmektedir (Tek, 2006: 69). Tüketicilerin satın alma davranışlarını açılayan temel modellerden biri Sheth vd. (1991) tarafından geliştirilen ve tüketicilerin ürünleri tercih etme sebeplerini ortaya koyan Tüketim Değerleri Teori'sidir. Çoğu mal veya hizmeti satın almanın altında yatan sebepler ve motivasyonlar tüketim değerleri ile açıklanabilmektedir (Candan vd., 2013: 30-31). Bu teori, tüketicilerin satın alma karar süreçlerini anlamlandırmada, yani tüketicilerin yaptıkları seçimleri neden yaptıklarını açıklamak için kullanılmaktadır (Turel vd., 2010: 54). Sheth vd. (1991), geliştirdikleri teoride beş tüketim değeri tanımlamış ve bu değerlerden oluşan tüketim değerleri modelini ortaya koymuşlardır. Teorideki bu değerler; fonksiyonel değer, sosyal değer, duygusal değer, yenilik değeri ve durumsal değerdir.

Fonksiyonel değerin genel anlamda tüketici tercihlerindeki en etkili faktörü olduğu varsayılmaktadır (Sheth vd., 1991: 160). Fonksiyonel değer, bireylerin rasyonel ve ekonomik değerlerini ifade etmektedir. Ürünün ve hizmetin kalitesi bu boyutu şekillendirmektedir (Khan, 2010: 378). Bu değerde tüketiciler öncelikli olarak bir ürünün taleplerini karşılayıp karşılayamadığı ve gerekli işlevlerini yerine getirip getiremediğini önemsemektedirler (Chang, 2008: 329).

Sosyal değer; ürünlerin sosyal sınıf, statü vb. olgular ile birleşmesinden ortaya çıan algısal bir fayda olarak ifade edilmektedir (Altıntaş, 2000: 114). Tüketicilerin davranışları ile içerisinde yer aldığı sosyal gruplar ve yaşantıları arasında anlamlı bir bağ bulunmaktadır. Referans grupları, roller ve statü gibi konular tüketicilerin davranışlarını etkileyen sosyal faktörlerdendir (Marangoz ve Aydın, 2017: 191).

Duygusal değer ise güven, heyecan vb. olumlu duygular veya korku, öfke vb. çeşitli duygusal durumlar gibi insan duyguları ile alakalı olan değerleri ifade etmektedir (Sánchez Fernández ve Iniesta Bonillo, 2007: 438). Bu değer, ürünlerin tüketiciler üzerinde uyandırdığı hislerde ve duygusal durumlarında ortaya çıkmaktadır (Sheth vd., 1991: 161).

Bir ürün veya hizmetin bireyler üzerinde merak uyandırma, yenilik sağlama veya bilgi edinme arzularını karşıladığı durumlarda yenilik değeri ortaya çıkmaktadır. Bütün yönleriyle yeni deneyimler, yenilik değeri ile ilişkilendirilebilir (Sheth vd., 1991: 162). Tüketicilerin yeni bir ürün veya hizmeti tüketir ya da deneyimlerken, yeni bir bilgisayar satın almak veya cep telefonu satın almak gibi durumlara ilişkin şekliyle açıllanabilmektedir (Bødker vd., 2009: 2). 
Son olarak, durumsal değer satın alma kararı alacak olan kişinin karşılaşmış olduğu birtakım spesifik durum veya koşulların sonucu olarak seçilen alternatifin ortaya çıkarttığı algılanan fayda olarak tanımlanmaktadır (Tek, 2006: 70-71).

\section{Yöntem}

Z Kuşağı tüketicilerinin tüketim değerlerini anlamaya yönelik yürütülen bu araştırmanın anakütlesini Türkiye'de yaşayan cep telefonu sahibi Z Kuşağı bireyleri oluşturmaktadır. Anakütlenin tamamına erişimin mümkün olmaması ve araştırmacının mevcut imkanları da göz önünde bulundurularak araştırmaya Muğla ilinin Menteşe ilçesinde yaşayan Z Kuşağı bireyleri dahil edilmiştir. Araştırma kapsamında cep telefonu ürünü tercih edilmesinin birtakım sebepleri bulunmaktadır. Z Kuşağının teknoloji çağında dünyaya gelmesi ve dünyada yaşanan teknolojik gelişmelerin cep telefonu ürünüyle doğrudan ilişkisi olması, evrensel ortak bir ürün çeşidi olması, cep telefonunun küçükten büyüğe herkesin hayatında büyük önem arz etmesi, hemen hemen herkesin şahsi ürün bağlamında bir cep telefonunun olması ve en önemlisi de tüketim değerlerinin mevcut tüm boyutlarına karşıllk verebilecek pratik bir ürün olduğu gerçeği cep telefonu ürününün bu araştırma için tercih edilmesindeki etkenler olduğu söylenebilir.

Çalışma nitel araştırma yönteminden faydalanılarak gerçekleştirilmiştir. Veri toplama yöntemi olarak ise görüşme (mülakat) tekniği kullanılmıştır. Araştırma örnekleminin belirlenmesine öncelikle kolayda örnekleme ile başlanmış olup sonrasında kimi durumlarda kartopu örneklemeye gidilmiştir. Bu gibi durumlar çoğunlukla daha nitelikli veriler elde edilebileceği düşünüldügünde gerçekleştirilmiştir. Nitel araştırmalarda örneklem sayısını miktarı ile değil, araştırmacının ihtiyacı olan bilgi miktarının örneklemden elde edilip edilemediğine, karşılayıp karşılamadığına bakılmaktadır. Bu sebeple, seçilen örneklemin temsil edilebilirlik gücünü ne kadar yansıttığıyla değil amaç odaklı seçimlerle hareket edilmektedir. Diğer bir ifadeyle, araştırmacının elde ettiği bilgilerin doyum seviyesine ulaşmaya başladığı anda örneklem sayısının yeterli olduğu söylenebilir (Türnüklü, 2000: 548). Buradan hareketle, araştırma kapsamında 14.01.2020 ve 18.02.2020 tarihleri arasında toplam 25 katılımcıya ulaşılmıştır. Bu görüşmeler sonunda 3 katılımcının verdikleri yanıtların tutarsızlığı veya yeterli bilgi paylaşımında bulunmadıkları gerekçesiyle araştırmaya dahil edilememiştir.

Araştırma Muğla Sıtkı Koçman Üniversitesi İnsan Araştırmaları Etik Kurulunun 22.06.2020 tarih ve 126 no'lu kararı ile yarı yapılandırılmış görüşme formu kullanılarak yürütülmüştür. Hazırlanan soru formunda 5 tüketim değeri (fonksiyonel, sosyal, duygusal, yenilik, durumsal) ve bu değerler ile alakalı toplam 20 adet soru bulunmaktadır. Soru formunun en sonunda ise katılımcıların demografik özelliklerinin bulunduğu bir bölüm yer almaktadır. Sorular; Yaşin (2007), Burucuoğlu (2016) ve Yıldırım'ın (2013) çalışmalarından faydalanarak yazarlar tarafından uyarlanmıştır. Oluşturulan ilk sorular öncelikle 5 kişilik pilot görüşmede test edilmiş, anlaşılmayan veya kusurlu olduğu saptanan sorular yeniden revize edilmiştir. Revize edilen bu sorular tekrar bir başka 5 kişilik pilot görüşmede test edilmiş ve soru forumuna son hali verilmiştir. Pilot araştırmalara katılan katılımcılar araştırmaya dahil edilmemiştir.

Veri toplama esnasında katılımcıların kendilerini rahat hissedebilmesi ve özgürce ifade edebilmeleri açısından görüşme yerlerini kendileri seçmeleri konusuna özen gösterilmiştir. Bunun sonucunda görüşmeler, her bir katılımcının belirlediği yerde ve saatte gerçekleştirilmiştir. Görüşülen yerlerin sessiz olmasına ve katılımcıların odağını dağıtacak şeylerin olmamasına dikkat edilmiştir. Görüşmeye başlamadan önce araştırmaya kendi istekleriyle katılma konusuna özellikle değinilmiştir. Öte yandan görüşmeyi ses kayıt cihazı ile kayıt etmek için de ayrıca izin istenmiş ve alınan izinler sonucunda tüm görüşmeler ses kayıt cihazı ile kayıt edilmiştir. Karşı tarafın görüşmede rahat davranabilmesi adına görüşme öncesinde kısa sohbetler edilmiş, araştırma hakkında bilgiler verilmiştir. Akabinde konuşma rahatlığına ulaştığı düşünülen katılımcılarla görüşmeye başlanmıştır. Görüşme esnasında katılımcıları olumlu veya olumsuz yönlendirilecek herhangi bir jest, mimik, tonlama gibi davranışlarda bulunmamaya dikkat edilmiş ve katılımcıları etkilememek için çaba gösterilmiştir. Katılımcıların bilgi aktarımına bağlı olarak görüşmeler ortalama 20 ile 40 dakika arasında sürmüştür.

\section{Bulgular}

Görüşme formunda yer alan soru ve temalar daha önceden belirlenmiş boyutlara göre oluşturulduğundan araştırma sonunda elde edilen verilerin analizi için betimsel analiz tekniğinden faydalanılmış, bulgular bu 
Ş. O. Çelebi - F. Bayrakdaroğlu 12/3 (2020) 3055-3070

bağlamda düzenlenmiş ve yorumlanmıştır. Görüşme süresince alınan yanıtların gizlilik esasına dayanmasından dolayı her bir katılımcıya bulundukları kuşağı yansıtan ' $Z$ ' harfi ile kodlama yapılmıştır. Katılımcıların kendine ait kodlamaları ile oluşturulan ses kayıtları dikkatle dinlenerek bilgisayar ortamına özenle aktarılmıştır. Bilgisayara aktarılan bu yanıtlar kontrol amaçlı bir kez daha ses kayıtlarıyla eşleştirme yapmak için gözden geçirilmiştir. Verilerin doğru bir şekilde aktarıldığına emin olunduktan sonra önceden oluşturulan temalara ve boyutlara göre düzenlemesi ve yorumlaması işlemi yapılmıştır. Araştırmaya dahil edilen katılımcıların demografik özellikleri Z harfi ile Tablo 1'de gösterilmektedir.

Tablo 1. Katılımcıların Demografik Özellikleri

\begin{tabular}{|c|c|c|c|c|c|}
\hline & Cinsiyet & Doğum Yılı & Eğitim Düzeyi & Cep Telefonu Marka ve Modeli & Ailenin Aylık Geliri \\
\hline $\mathrm{Z1}$ & Kadın & 2005 & Lise Öğrencisi & Samsung A7 2018 & $4501-5500$ \\
\hline $\mathrm{Z} 2$ & Kadın & 2005 & Lise Öğrencisi & Vestel Venüs V3 & $3501-4500$ \\
\hline $\mathrm{Z3}$ & Erkek & 2000 & Lise Mezunu & Apple Iphone 7 & 6501 ve üzeri \\
\hline $\mathrm{Z} 4$ & Erkek & 2002 & Lise Mezunu & Huawei Y7 2019 & $3501-4500$ \\
\hline $\mathrm{Z} 5$ & Erkek & 2005 & Lise Öğrencisi & Samsung Galaxy S6 & 6501 ve üzeri \\
\hline Z6 & Erkek & 2003 & Lise Öğrencisi & LG V20 & 6501 ve üzeri \\
\hline $\mathrm{Z7}$ & Kadın & 2000 & Lise Mezunu & Apple Iphone 6 Plus & $4501-5500$ \\
\hline $\mathrm{Z} 8$ & Erkek & 2006 & Ortaokul Öğrencisi & Samsung Galaxy J7 Prime & $5501-6500$ \\
\hline Z9 & Kadın & 2003 & Lise Öğrencisi & Samsung Galaxy J7 & $2300-3500$ \\
\hline $\mathrm{Z} 10$ & Kadın & 2003 & Lise Öğrencisi & Apple Iphone $6 \mathrm{~S}$ & $4501-5500$ \\
\hline Z11 & Erkek & 2000 & Üniversite Öğrencisi & Apple Iphone $5 S$ & 6501 ve üzeri \\
\hline $\mathrm{Z} 12$ & Kadın & 2005 & Lise Öğrencisi & Samsung A50 & 6501 ve üzeri \\
\hline Z13 & Erkek & 2006 & Ortaokul Öğrencisi & Casper Via M3 & $5501-6500$ \\
\hline Z14 & Erkek & 2000 & Lise Mezunu & Samsung J7 Prime & $2300-3500$ \\
\hline $\mathrm{Z} 15$ & Kadın & 2002 & Lise Öğrencisi & Apple Iphone 7 Plus & $4501-5500$ \\
\hline Z16 & Kadın & 2000 & Üniversite Öğrencisi & Apple Iphone X & $2300-3500$ \\
\hline Z17 & Kadın & 2000 & Lise Mezunu & Apple Iphone 8 Plus & $5501-6500$ \\
\hline Z18 & Erkek & 2000 & Lise Mezunu & Samsung J3 & $5501-6500$ \\
\hline Z19 & Kadın & 2000 & Üniversite Öğrencisi & Apple Iphone 6 & 6501 ve üzeri \\
\hline $\mathrm{Z} 20$ & Kadın & 2000 & Üniversite Öğrencisi & Apple Iphone $6 \mathrm{~S}$ & 6501 ve üzeri \\
\hline $\mathrm{Z} 21$ & Erkek & 2004 & Lise Öğrencisi & Samsung J7 & $3501-4500$ \\
\hline $\mathrm{Z} 22$ & Kadın & 2003 & Lise Öğrencisi & Apple Iphone 6 & 6501 ve üzeri \\
\hline
\end{tabular}

Tablo 1 incelendiğinde katılımcıların \%54,5'inin (12) kadın, \%45,5'inin (10) ise erkek olduğu görülmektedir. Katılımcıların doğum tarihlerine göre dağılımında 2000 doğumlu \%40,9 (9), 2002 doğumlu \%9 (2), 2003 doğumlu \%18,1 (4), 2004 doğumlu \%4,5 (1), 2005 doğumlu \%18,1 (4) ve 2006 doğumlu \%9 (2) birey bulunmaktadır. Eğitim seviyelerine göre \%9'u (2) ortaokul öğrencisi, \%45,4' ü (10) lise öğrencisi, \%27,2'si (6) lise mezunu ve \%18,1'i de (4) üniversite öğrencisidir. Araştırmaya katılanların \%81,8'inin (18) Apple ve 
Ş. O. Çelebi - F. Bayrakdaroğlu 12/3 (2020) 3055-3070

Samsung marka cep telefonu kullandığı görülmektedir. Apple markasını kullanan katılımcıların ise genel anlamda aile gelirinin yüksek olduğu göze çarpmaktadır.

Fonksiyonel Değerle İlgili Bulgular

Araştırma kapsamında katılımcılara fonksiyonel değer ile ilgili yönlendirilen sorular ve katılımcıların bu değer boyutu ile ilgili vermiş olduğu yanıtlar şu şekildedir:

Soru 1) Cep telefonu satın alırken, ihtiyaçlarınızı karşılayacak işlevsel (kamera kalitesi, batarya kapasitesi, telefon ağırlı̆̆ı, ekran boyutu vb.) özellikler, satın alma tercihinizi etkiler mi?

Görüşmeye katılan katılımcıların tamamı cep telefonunda kendi ihtiyaçlarını karşılayacak fonksiyonel özelliklerin satın alma tercihlerinde çok önemli bir kriter olduğunu belirtmişlerdir. Üstelik katılımcıların bazıları, fonksiyonel özelliklerin satın alma tercihlerindeki en önemli kriterleri olduğunu da açıkça dile getirmektedir;

"Tabii ki evet. En çok bunların etkilediğini söyleyebilirim. (Z1)", "Evet çünkü ben telefonu çok kullandiğım için etkiler, bayağı etkiler hem de. Benim için bayağı önemli bir konu bu. (Z2)", "Ya evet başka bir şey etkilemez sadece bunlar etkiler hatta. (Z6)"

Bireyler, telefonların sahip olduğu birçok fonksiyonel özelliklerin satın alma tercihlerindeki etkilerinden bahsetseler de en çok önem verdikleri özelliğin kamera kalitesi olduğuna değinmektedirler;

"Etkiler, nasıl etkiler. Yani alacağım telefonun bütçeme göre kamerasının iyi olmasını isterim. Ne bileyim hafizasının yüksek olmasın isterim. Hafif olmasını, çok büyük olmamasın isterim (...). (Z4)", "Etkiler çünkü ben kamerayı çok aktif kullanan bir insanım. Benim kendi aktifliğimi göstermem, kendimi daha iyi hissetmem için sonuçta telefonun daha çok kullanışl özelliklerini seçmem gerekiyor. Kamera olabilir, ekran büyüklüğ̈̈ olabilir gibi. (Z7)", "Benim için en çok etkileyen şey kamera, fotoğraf kalitesi. Ben fotoğraf çekmeyi ve çekilmeyi çok seviyorum (...). (Z16)"

Soru 2) Cep telefonunun faydalı özelliklere sahip ve kullanışlı olması, diğer tüm faktörlerden (fiyatı, görünüşü vb.) daha önemlidir denilebilir mi?

Katılımcıların tamamı fonksiyonel özelliklerin satın alma tercihlerinde etkisi olduğunu belirtse de büyük bir çoğunluğu telefonların yalnızca faydalı ve kullanışlı özelliklere sahip olmalarının yetersiz olduğunu ifade etmektedir. Faydalı ve kullanışlı özelliklerin haricindeki faktörler dahilinde en göze çarpan değişkenin ise telefon fiyatları olduğu görülmektedir;

"Hayır çünkü hani özellikleri gayet iyidir ama kendi bütçemizi de düşünmemiz gerekir (...). Fiyatı ve başka özellikleri de bu konunun içinde tutulmalı. (Z20)", "Alacă̆ım telefonda özelliklerinin iyi olması ilk tercihimdir ama ailemin veya kendi bütçeme zarar verecekse neden satın alayım (...) (Z22)", "Belli bir bütçe koyulur zaten ortaya, o fiyata en uygun özellikleriyle en benimsediğim şekilde olanı tercih ederim. Birbirinden ayıramam bunları. (Z19)"

Diğer yandan katılımcılar kullanışlı özelliklerin yanı sıra hissiyatın da önemli olduğunu, kendilerini iyi hissetmek istediklerini, bu iki unsurun bir bütün olarak ele alınması gerektiğini ve bu sebeple yalnızca özelliklerin yeterli gelmediğini şu sözlerle belirtmektedirler;

"Yani, yok. Her şeyiyle güzel olmalı telefon. Evet boyutu ve kamerası da iyi de hani böyle telefonu yanıma koyduğumda da iyi ki almışım gibi hissetmek istiyorum. (Z12)", "Aslında diyemem sonuçta özellikleri çok iyi olup telefonun görünüşü absürt ise ya da ergonomik falan değilse yani bir soğurum aslında telefondan, rahatsız eder (...). (Z14)", "Faydah olsun ama diğer her şeyden de soyutlayamam (...). (Z18)"

Soru 3) Cep telefonunu estetik görünümü olan bir aksesuar olarak mı, yoksa ihtiyaçlarınızı karşılayan kullanışlı bir araç olarak mı ifade edersiniz?

Katılımcılardan alınan yanıtlar doğrultusunda cep telefonunun yalnızca aksesuar olarak görüldüğü, bir araç olarak görülmediği bulgusuna rastlanılmamıştır. Diğer yandan düşük oranda da olsa telefonun yalnızca araç olarak görülüp aksesuar yönleri ile bağdaştırılamayan cümlelere de rastlanmaktadır;

"Bence sadece ihtiyaçlarımı karşılayan kullanışlı bir gereç, araç. (Z13)", "Cep telefonu benim için ihtiyaçlarımı karşılayan bir araç. Bunun gösterişle bir ilgisi yoktur diye düşünüyorum (...). (Z4)" 
Ş. O. Çelebi - F. Bayrakdaroğlu 12/3 (2020) 3055-3070

Genel bağlamda katılımcıların çoğu cep telefonlarını hem bir araç hem de bir aksesuar olarak lanse etmektedir. Fakat verdikleri yanıtlar doğrultusunda bir ağırlık derecesinin olduğu görülmekte, terazinin ağır tarafında ise telefonların kullanışlı araçlar olduğu düşüncesi bulunmaktadır;

"Her ikisini de düşünürüm yani çünkü günümüzde cep telefonları çok fonksiyonlu (...). (Z3)", "Yani ihtiyaçlarımı karşılayacak bir araç olarak görüyorum ama estetik bir görünüş olarak da görüyorum (...) (Z10)", " Estetik görünümü olan bir aksesuar da oluyor. Mesela Instagram'a fotoğraf atarken böyle kahvenin yanına falan telefonu koyuyorlar ya, onu seviyorum. (...). Kamerası da benim için çok önemli olduğundan ikisini de olur. (Z17)"

Sosyal Değerle İlgili Bulgular

Sosyal Değerle alakalı Z Kuşağı tüketicilerine yönlendirilen sorular ve katılımcılardan alınan görüşlere aşağıda yer verilmektedir:

\section{Soru 1) Cep telefonu satın alırken arkadaşlarınızın ve çevrenizin alacağınız telefonu beğenmesi sizin için önemli midir?}

Tüketicilerin cep telefonu satın alırken çevrelerinin düşüncelerine duydukları beğenilme kaygısı üzerine sorulan bu soruda katılımcıların birçoğu kendilerinin telefon hakkındaki düşüncelerinin bu aşamada en değerli olgu olduğunu belirtmektedir. Tüketime konu olan ürünün sahibi olduklarını ve bu doğrultuda ürün üzerindeki işlevsel çıkarları ön planda tuttukları şu sözlerle görülmektedir;

"Bence o kadar önemli değil çünkü telefonu sonuçta ben kullanacağım ve büyük ihtimalle de uzun bir süre o benim elimde olacağı için benim kararlarım daha önemli. (Z8)", "Aslında öncelikle telefonu benim beğenmem önemli. Çünkü hani o telefonu ben kullanacă̆ım yani çevremdeki insanlar kullanmayacak (...). (Z16)", "Önemli değil çünkü ben kendi beğendiğgim bir markanın ürününü alırım (...). (Z17)", " Önemli değildir. Benim beğenmem daha önemli. $(\mathrm{Z} 21)^{\prime \prime}$

Öte taraftan sosyal çevreyi dikkate alan azınlıktaki katılımcıların asıl probleminin beğenilme kaygısı değil beğenilmeme korkusu olduğu ön plana çıkmakta ve çevrelerine karşı küçümsenmemek, kendilerini kötü hissetmemek adına böyle bir davranışa giriştikleri şu sözlerle ortaya konulabilmektedir;

"Evet, önemli çünkü hepimiz sürekli aynı ortamlarda bulundŭ̆umuz için ve ne bileyim kamera kalitesi falan gibi şeyler benimkinden iyi ise kötü olurum ama mesela benimki onunkinden daha iyiyse bu beni daha iyi hissettirebilir. (Z1)", "Yani önemli ama şu açıdan önemli mesela arkadaşlarımın daha iyi bir telefonu vardır ya da benim daha kötü bir telefonum olursa onu küçümserler falan gibi yani onu düşünürüm, o yüzden dikkat ederim yani görüşlerine. (Z10)"

Son olarak bu konuda çekingen davranan kişilerde de beğenilmeme korkusunun bulunduğu fakat diğer yandan kendi isteklerini de göz ardı etmeyecekleri tarzda ifadeler bulunmaktadır;

"Yani, yani çok değil kendi fikrim tabii ki daha önemli ama biraz önemli. Biraz derken de mesela benim moralim bozulabilir belki beğenmezlerse diye yoksa benim beğenmem daha önemli sonuçta ben kullanacă̆ım. (Z10)", "Açıkçası önemli değil, sonuçta cep telefonu dediğimiz kişisel bir şey. Ben illa ki güzel olmasın isterim, insanları beğenmesini isterim ama beğenmezlerse de benim için önemli değil yani. (Z14)"

Soru 2) Yerinde olmak istediğiniz ya da kendisine benzemek istediğiniz kişilerin sahip olduğu telefon marka ve modellerini tercih etmeye çalışır mısınız?

Oldukça az bir kitle dışında katılımcıların büyük bir kısmı rol model aldıkları kişilerin cep telefonlarını tercih etmediklerini/etmeyeceklerini belirtmektedir. Fakat tam anlamıla bir soyutlama söz konusu olmamaktadır. Yani başta kendi beğenileri ve kullanacakları telefonların işlevsel çıkarlarına uygunluğunu ön planda tutarak bu tür kimselerin tavsiyelerini dinleyecekleri sonucu da ifadelerine yansımaktadır;

"(...) Çalışmam ama tabii ki önerilerine yani şu şu özellikleri daha kullanışlıdır yani onların reklam ettikleri kullanışl özelliklerine göre seçim yapar mıyım yaparım ama yine de sırf onlar kullanıyor diye kör kütük gidip almam, ilk önce bir araştırırım. (Z3)", "Yani özelliklerine bağgl tercih edebilirim. Bir kişiyi rol model alıyorum diye telefonunu direkt alayım gibi bir şey olmaz (...). (Z9)", "Bazı tanınmış insanların düşüncelerini dinlerim ama her zaman için ilk önce benim düşüncelerim daha önemli. Benim rahat edebildiğim bir telefon almam daha önemli. (Z15)"

Bir kısım katılımcılar ise bu konudaki düşüncelerini olmak istedikleri kişilerdeki karakter ve kişilik özellikleriyle bağdaştırmakta, cep telefonlarının başkası olma arzusunda yeri olduğunu düşünmemektedir; 
Ş. O. Çelebi - F. Bayrakdaroğlu 12/3 (2020) 3055-3070

"Aslında benim şu anda özendiğim biri var ama onun cep telefonu bile yok, (...). Bu tarz durumda ürünler değil karakter daha önemli. (Z8)", "Maddi açıdan değil ama karakter açısından anneme ya da teyzeme benzemek isterdim (...) ama telefonun bununla bir alakası olduğunu düşünmüyorum. O sadece bir eşya. (Z10)", "Hayır, çalışmam çünkü yani ona benzemek istiyorsam yani onun kişilik özelliklerine bakarm. (...) telefonu benim için önemli değil yani. (Z11)"

\section{Soru 3) Bir cep telefonu satın almadan önce arkadaşlarınızdan ve çevrenizden telefon hakkında bilgi toplar misiniz?}

Bireylerin cep telefonlarını satın almadan önce çevresindeki insanlardan bilgi toplaması konusunda tüm katılımcıların fikir birliği içerisinde olduğu görülmektedir. Cep telefonlarının fonksiyonel özelliklerinin satın alma tercihinde önemli bir kıstas olduğundan yola çıkarak, katılımcılardan alınan cevapların bu konu ile paralellik gösterdiğini söylemek mümkündür. Kullanıcılar, telefonların özellik ve donanımları hakkındaki sorularını yine cep telefonu ile ilgili veya kendinden daha bilgili gördüğü kişiler vasıtasıyla yerine getirmektedir:

"Evet, onlarm böyle teknolojiyle ilgili olan kişileri düşünürüm (...). Birkaç kişiden toplarım eğer herkes aynı fikirdeyse o telefona yönelirim (...). (Z12)", "Bilgi toplarım çünkü benden daha iyi telefonla alakah olan kişilerden bilgi toplarm (...). (Z13)"

Yine aynı soru ile alakalı yanıtlar incelendiğinde katılımcılar kendilerinden daha bilgili kişilerin yanı sıra başkalarının kullanıcı deneyimlerine güvendiklerini ve bu konuda faydalanmak istediklerini dile getirmektedir:

"Evet, toplarım. Çünkü bilmediğim bir cep telefonunu almak istemem. Yani bir ön bilgi almak, onlardan bilgi toplamak isterim. Bu kişiler telefonu deneyimlediği için onlardan daha güzel bilgi alabilirim. (Z2)", "Kullanan biri varsa tabii ki toplarım (...). (Z7)", "Bilgi toplarım kesinlikle özellikle uzun süre kullanmış insanlara sorarım çünkü etkileri neler, aldıktan sonra ne kadar uzun ömürlü dayanabiliyor (...) o insanlar bunu almışlar ve deneyimlemişler. Almayı düşünüyorsam onlarm da benimle deneyimlerini paylaşmaların isterim ve bunu da göz önünde bulundururum. (Z16)"

Soru 4) Bir cep telefonunun, yeni tanıştığınız insanların ilk izlenimleri üzerinde etkisi olduğunu düşünüyor musunuz?

Belirtilen soruya verilen yanıtlar incelendiğinde eşit sayılara yakın bir dağılım olduğunu dile getirmek mümkündür. Olumlu alınan yanitların bir miktar daha fazla olduğu göre çarpsa da, olumsuz düşünenlerin sayısı da bir o kadar fazladır. Cep telefonu model ve markasının insanların ilk izlenimleri üzerinde etkisi olduğunu düşünen Z Kuşağı bireyleri genelde maddi yargılamalarda bulunmaktadır;

"(...) Kişisel özellikleri açısından değil, ama maddi olarak diyebilirim ne bileyim örneğin Iphone X falan üstüyse mesela kullandığı telefon durumları iyidir herhalde derim (...). (Z4)", "Maddi olarak evet. Mesela telefondan ne çıkarırsın dersen telefondan maddi durum analizi yapıyorsun (...). (Z18)"

Ayrıca dile getirilmesi gereken diğer bir nokta, kendileri reddetse dahi toplum bazında veya çevrelerindeki insanlarda böyle bir algının var olduğuna dair farkındalıklarını belirten kişiler mevcuttur. Bu kişiler, yöneltilen soruya kendileri açısından olumsuz yaklaşsalar bile bu algının varlığına olumlu baktıklarının altını çizmektedirler:

"Bizzat benim gözümde cep telefonunun böyle bir izlenimi yok ama bence insanlar üzerinde kesinlikle bir izlenim yaratıyor (...). (Z3)", '"(..) Ben böyle düşünmüyorum, ben yargılamam ama etrafın yargıladığını düşünüyorum. (Z9)", "Yani çevremde zenginlik göstergesi gibi davranan insanlar fazla, mesela Iphone 11 çıktı, çıktığı günden sonra hemen değiştirenler için insanlar öyle düşünüyor olabilir (...). Kendi adıma böyle bir şey söz konusu değil ama başkaları adına böyle düşünüyorum. (Z19)"

Olumsuz boyutta incelendiğinde ise sahip olunan cep telefonu marka/modeli ile insanların karakteristik veya kişilik özellikleri hakkında bir çıkarım yapılamayacağı görüşü hakim görünmektedir;

"Insanları tanımadan izlenim elde edemeyiz. Telefonlarına, kıyafetlerine, yaşam tarzlarına bakarak fikir elde edemeyiz (...). (Z5)", "Hayır, düşünmüyorum. Mesela benim bazı arkadaşlarım var onlar böyle kendilerini soyutlamışlar tuşlu falan kullanıyorlar ama çok iyi insanlar yani, çok kaliteli fikirleri düşünceleri olan insanlar yani bu yüzden düşünmüyorum. (Z17)", "Düşünmüyorum hayır. Sahip olduğu bir telefona bakarak insan yargılayamayız. (Z21)" 
Ş. O. Çelebi - F. Bayrakdaroğlu 12/3 (2020) 3055-3070

Soru 5) Cep telefonu marka veya modelinin, insanların sosyal statülerini gösteren bir sembol ürün olduğunu düşünüyor musunuz?

Z Kuşağının cep telefonlarını sosyal statü sembolü olarak görmediği algısı verilen yanıtlar içerisinde çoğunluğu kapsamaktadır. Bu yönde görüş belirten kişiler sosyal statünün yalnızca telefonla ilişkilendirilemeyeceğini, hedeflenen telefona ulaşabilmenin herkes tarafından mümkün olabileceği, telefonların kişisel bir tercih olduğu gibi konulara değinmektedir;

"Bence etkisi yok çünkü mesela benim çok arkadaşım var, arkadaşlarımın babası müdür, patron gibi şeyler ama kullandikları telefon tuşlu telefon ya da ne bileyim dokunmatiğin bir düşük seviyesi (...). (Z10)", "Yok düşünmüyorum. Aslinda eğer paran varsa veya biriktirmişsen kendi sosyal statüne ait olmayan bir şeyi de alabilirsin. (Z14)", "Bence bir sosyal statü belirtmez çünkü telefonlar belirli bir sinıf veya toplum için üretilmez. Öyle olsaydı durumu iyi olan ile kötü olan arasında çok ciddi sorunlar çıkardı ve yeni bir ürün satışa ilk çıkarken teknoloji mağazalarının önünde bekleyen insanların tamamının durumunun çok iyi olması gerekir. (Z22)"

Öte yandan bu konuda olumlu görüş belirten Z Kuşağı bireylerinin bir kısmı ise sosyal statünün maddiyat boyutuna değinmekte ve bu boyutu çoğunlukla Apple markası ile bağdaştırmakta, cep telefonu ve sosyal statü ilişkisini bu iki değişken üzerinden kurmaktadır;

"Evet. Apple ve diğer Android modeller olarak söyleyebiliriz (...). Mesela ben Iphone seviyorum ama annem asla Iphone kullanmam diyor, bu değişken bir durum. Diğer yandan Iphone sahibi olan insanları iş adamı iş kadını gibi de adlandırabiliyoruz. (Z16)", "Evet kesinlikle öyle düşünüyorum. Iphone'un ve Apple markasının diğerlerine göre daha fazla ağırlı̆̆ı olduğunu düşünüyorum niyeyse (...). (Z20)", "Düşünüyorum. Çünkü telefonlarm serileri var ve insanların maddi durumları yetemeyebilir. Herkes alamaz o yüzden en yüksektekini, en yüksek modelini (...). (Z21)"

Duygusal Değerle İlgili Bulgular

Tüketim değerlerinin diğer bir boyutu olan duygusal değerler ile alakalı oluşturulan sorular ve katılımcıların verdikleri yanıtlar aşağıda paylaşılmaktadır.

Soru 1) Cep telefonu satın alırken duygularınıza (heyecan, güven, öfke, sevgi vb.) veya hislerinize göre hareket eder misiniz?

Z Kuşağı bireylerinin verdikleri yanıtlar incelendiğinde genel anlamda duygularını veya hislerini satın alma esnasında ya da satın alma araştırmalarını yaparken kullanmadıklarını belirtmektedirler. Bu süreçte daha çok telefonların işlevsel özelliklerini ön planda tuttuklarını veya genel bir mantık çatısı altında satın alma davranışlarını gerçekleştirdiklerini dile getirmektedirler:

"Yok bence hiç duygularla alakası yok (...). Önemli olan özelliği, duygularla alakası yok. (Z8)", "Yok, kesinlikle onlara göre hareket etmem yani alacağım telefonda önemli olan bunlar olmaz. Benim için işlevsel özellikleri daha değerli. (Z11)", "I-ih. Genelde daha mantıkl hareket ediyorum işte özellikleri, fiziksel özellikleri, teknolojik özellikleri ya da fiyatı. Duygusal değil de biraz da mantıklı hareket ettiğimi düşünüyorum bu konuda. (Z20)"

Duygularını cep telefonu satın alma aşamasında dahil ettiğini ifade eden katılımcılarda ise bir yargı göze ilişmektedir. Birkaçı duygularının satın alma aşamasında ortaya çıktığı söylerken bunu telefon markası üzerinden dile getirmektedir. Yani bir markaya duydukları güvenin satın alma aşamasında kendilerine rehberlik ettiklerinden bahsetmektedir;

"Markaya güvenebiliyorum ve bu almamda etkili olabiliyor (...). Ben daha çok yani yıllardır Iphone kullanıyorum (...). O marka bir isim duyurduğu için bana bir güven vermiş. Ben de ondan dolayı telefonlarımı buna göre tercih ediyorum. (Z15)", "Evet. Mesela önceden Samsung kullanmışımdır ve pat yere düştü kırıldl. Ben nefret ederim ondan. Iphone kullanmışımdır 5-6 kere yere düşmüştür ve bir şey olmamıştır Iphone'a daha bir güvenle bakarım. Bu sefer yeni telefon almaya gittiğimde "Geri**** Samsung, bir yere düşünce kirlliyor hiç sağlam değil" derim (...). (Z16)", " (...) Hazırlıklı olarak ne alınacağı kesin bir şekilde gidip alırız yani o an duygularımın yeri yok (...). Duygularım içinde de araştırma esnasında marka olayı olarak girmiştir. (Z19)"

Soru 2) Aklınızda cep telefonu satın alma kararı olmasa bile bir cep telefonunu gördüğünüzde sizde heyecan veya benzeri bir duygu uyandırması satın almanız için yeterli bir unsur mudur?

Tek başına duyguların yeterli bir uyaran olmadığı hakkında katılımcıların tamamı bir görüş birliğine sahiptir ve bu konuda net ifadeler kullanmaktadırlar. Kimileri ihtiyaçlarını karşılayan özelliklerin daha önemli bir 
Ş. O. Çelebi - F. Bayrakdaroğlu 12/3 (2020) 3055-3070

etken olduğundan bahsedip fonksiyonel değere gönderme yaparken kimileri ise bu iki değişkenin birbirini etkilediğinden bahsetmektedir;

"Değildir. Özellik bakımından da önemlidir telefonlar her zaman. Duygularımızla her zaman hareket edemeyiz, telefonları özelliklerine bakarak da hareket etmeliyiz. (Z5)", "Hayır, özellikleri, fiyatı vs. her şeyi benim için önemlidir. (Z9)", "Değil, özellikleri benim için daha önemli. Hislerimden ziyade işlevselliği yani. (Z11)", "İşlevsel özellikleri güçlü ve yeni çıan telefonlar ancak beni heyecanlandirabilir. Ancak bu sebeple satın alabilirim. (Z13)"

Soru 3) Cep telefonu satın alırken, telefonun sizi iyi hissettirmesi mi yoksa özellikleri ve fiyatı gibi kriterler mi daha önemlidir?

Cep telefonunun yalnızca heyecan veya benzeri olumlu duygular ile satın alınmasının yetersiz olduğu konusunda hem fikir olan Z Kuşağı bireyleri bu soruya da benzeri yanıtlar vererek bu durumu pekiştirmişlerdir. Telefonların yalnızca kendilerini iyi hissettirmelerinin yetersiz kalacağı konusunda yine ortak görüşleri olan katılımcıların bazıları ise doğrunun diğer bir ucu olan rasyonel konuların önemli olacağını belirtmektedirler;

"Daha çok diğer şeyler ya, o hissetme şeyine alışabilirim (...). Benim için önemli olan işlevsel şeyleri. (Z6)", "Özellikleri önemli benim için. Özelliği iyi olunca kendi kendine iyi hissettiriyor aslında. (Z9)", "Özellikleri ve fiyatı gibi konular daha önemli bana göre. (Z7)"

Asıl büyük çoğunluğu oluşturan grubun ise özellik ve fiyat gibi konuların ağırlıklı olarak hissedildiği fakat genel manada iki tarafı da dengeli olarak gören katılımcılar olduğunu söylemek mümkündür. Yine bu cevaplar arasında dikkat çeken nokta ise aslında telefonun sahip olduğu özelliklerin iyi bir hissiyat duygusunu yarattığı algıdır. Yani telefonun duygulara yönelik iyi bir şeyler hissettirebilmesi için rasyonel şeylerin varlığının mutlak olması ve kişileri bu yönden tatmin etmesi gerektiğidir;

"Aslında ikisi de önemli benim için çünkü hem ben kullanacağım hem de bataryası önemli, kamerası önemli çünkü aktif şekilde kullandığım için. Hem de bana bir his uyandırması gerekiyor, ikisinin de olması lazım mutlaka diyebilirim. (Z2)", "İkisi de önemli. Mesela ben kullandığım telefondan memnun olmalıyım. O da beni iyi hissettirir. Özellik bakımından falan, kalitesi iyi olmalı ki bunlarm ikisi beni birlikte iyi hissettirir. (Z5)", "Özellikleri ve fiyatı da zaten seni iyi hissettiren faktörler değil mi? (...). (Z18)"

Soru 4) Bir cep telefonu hangi üstün özelliklere sahip olursa olsun, içinize sinmediği takdirde yine de satın alır misiniz?

Genel anlamda cep telefonuna dair hissiyatı ve rasyonel özellikleri bir bütün olarak gören katılımcılar bu soru karşısında da ortak görüşlerini beyan ederek konuyu daha da desteklemişlerdir. Fakat burada dikkat edilmesi gereken nokta şudur ki; daha çok özelliklere odaklandıklarını ifade eden kullanıcılar en iyi özelliklere sahip olan telefonu alma fırsatları olduğunda bile hissiyat konusunu göz ardı etmemektedir. Yani cep telefonlarında direkt duygularına yönelik tercihlerde bulunmasalar bile tamamıyla bağımsız gördükleri de söylenememektedir;

"Almam. Özellik bakımından iyi olsun ama memnuniyet de önemli. Mesela bu telefona bakıyorum ve başka bir telefona da bakıyorum. Özellik bakımından ikisi de aynıysa hangisinden daha memnun hissettiysem onu alırm. (Z5)", "Paramın olduğunu farz ediyorum, almam. Çünkü bunu yanımdan ayırmıyorum mesela, gün boyu hep benimle să̆ cebimde onun dışında uyurken sehpanın üzerinde. Ĕ̆er içime sinmeyen bir şey varsa bunu bu kadar yanımda taşımak istemem ve taşımak istemediğim bir şeyi de almam yani. (Z14)"

Yenilik Değeriyle Ilgili Bulgular

Z Kuşağı üyesi katılımcılara yöneltilen yenilik değeri ile alakalı tüm sorular ve katılımcılardan alınan cevapların bazıları şu şekildedir:

\section{Soru 1) Satın alma amacınız olmasa bile yeni çıkan cep telefonlarını ve özelliklerini incelemekten hoşlanır misiniz?}

Katılımcıların tamamına yakını yeni çıkan cep telefonları hakkında bilgi toplamaktan hoşlandıklarını belirtmektedir. Amaçlarından bazılarını ise kendi telefonları ile kıyaslamalar yapmak, teknoloji ve yenilikler hakkında bilgi sahibi olmak gibi sebeplerin oluşturduğunu söylemek mümkündür. Öte yandan Apple markasını da teknoloji ve yenilik konusunda öncü bir firma olarak gördükleri de dile getirilebilir; 
Ş. O. Çelebi - F. Bayrakdaroğlu 12/3 (2020) 3055-3070

"Evet, hoşlanıyorum. Teknolojinin ne kadar ilerlediğini buradan anlayabiliyorum. (Z13)", "Evet hoşlanıyorum. Kesinlikle hoşlanıyorum diyebilirim. Reklam çıkıyor mesela televizyonda, Apple'ın genellikle çok ilgi çekici bir reklamı oluyor yeni çıkan telefonları için, o zaman kendi elinde tuttuğun telefonla kıyaslıyorsun (...). (Z20)", "Evet. Mesela ben şimdi Iphone 6 kullanıyorum ama 11'in özelliklerine falan da bakıyorum yani neler değişmiş neler yapmışlar. Kullanan arkadaşım varsa da elime alip inceliyorum. (Z19)"

Birtakım cep telefonu kullanıcılarının ise yeni cep telefonu ve özellikleri hakkında pek ilgili olmasalar dahi çevrelerinde kullananlar var ise bu kişiler vasıtası ile deneyimlemek, görmek ve incelemek istedikleri görülmektedir;

"Açıp bakmam Google'dan falan ama arkadaşım almışsa incelemeyi isterim. Çevremdeki insanların telefonlarını incelemekten hoşlanırım diyebilirim. (Z1)", "Yani bir mağazaya girip sürekli telefonlara bakmam. Ama arkadaşımın telefonunu görüp onu incelerim, merak ederim, kamerasına bakarım büyüklüğ̈̈̈ne falan (...). (Z10)"

\section{Soru 2) Cep telefonu ile ilgili teknolojik gelişmeler sizde merak uyandırır mı?}

Bir önceki soruya olumlu yanıt veren kişilerin hemen hemen hepsi bu soruya da olumlu cevap vermektedir. Burada dikkat çeken nokta ise bu teknolojik gelişmeleri takip etme arzusunun kişisel bağlamlarda genişleyip farklılık gösterebildiğidir. Yani katılımcıların birçoğu teknolojinin gelişimi, hayatımızdaki yerinden kaynaklı bir ilgi boyutu oluştururken başka kişiler ise teknolojik gelişmelerin pazarlama yönüyle de ilgilendiğini ifade etmektedir;

"Evet, uyandırıyor. Özellikle yeni bir telefon tanıtımı yapılacağı zaman canlı yayına veriyorlar zaten (...). Çünkü daha çok telefon tanıtımından ziyade -zaten görüntüleri genelde sızdırllyor ama- önemli olan sahneye çıkanın onu nasıl pazarladığı, o birlik şeyi nasıl beşlik anlattığı bende merak uyandırıyor. (...) her çıkan telefon aslında yeni bir teknolojinin tanıtımı ama bunun pazarlama boyutu da benim hoşuma gidiyor. (Z3)", "Evet, mesela gezdiğim çoğu sayfa da falan teknolojiyle alakalı çünkü bu bir yenilik. Bu teknolojinin telefonda olması benim daha çok ilgimi çekiyor. (Z8)", "Evet, en son Samsung'un çift telefon (katlanabilir) olayı vardı. Ben mesela onu gördü̈̆̈̈̈mde beynim uçtu yani. Bilmiyorum beni çok çekti o özelliği. Çünkü iki telefon alıyorsun ama tek bir cihazda. Hem tablet oluyor hem telefon falan. Şöyle söyleyeyim, 2 saat 20 dakikalık bir canlı yayın vardı, izledim. Tamamını izledim. Ya böyle biri geliyor işte bir pazarlamacı geliyor. O bir özelliğini tanttıyor, o iniyor sonra başka adam geliyor o özelliğini anlatıyor ben de ă̆zım açık izliyorum. (Z14)"

\section{Soru 3) Beğendiğiniz bir cep telefonuna sahipseniz, sizinkinden daha üstün özellikli yeni telefon modelleri çıksa bile değiştirmeyi düşünür müsünüz?}

Katılımcıların birçoğu eğer sahip oldukları cep telefonunun kendilerine yeterli geldiklerini düşünüyorlarsa yeni bir telefon satın almanın gereksiz olduğundan bahsetmektedir;

"Yok, elimdeki telefonum benim ihtiyaçlarımı karşıladığı sürece pek fazla ilgilenmiyorum yani hangi telefonun çıktığı falan beni şey yapmaz (...). (Z2)", "Eğer şu an mevcut telefonum beni kurtarıyorsa eğer yeni çıkan telefonu alacak param olsa bile almam (...). (Z3)", "Yok değiştirmem hayır. Benimki o an benim için yeterliyse, yeterlidir. (Z6)".

Yine cep telefonları kendilerine yeterli olduğunda değiştirmeyeceğini söyleyen katılımcılar ancak birtakım bozulma ve kırılma gibi şartlı durumlarda yani telefonun işlevsiz kalacağı durumlarda değiştirebileceklerini ifade etmektedir;

"Hayır, benim için telefonun bir limiti var, kırılırsa, ekranı çatlarsa ya da üç seneden fazla kullanmışsam öyle değiştiriyorum (...). (Z15)", "Yapmam bunu. Bende şey yani, artık gerçekten telefon kullanılmayacak hale gelsin o zaman alırm derim. (Z19)"

Diğer taraftan bazı katılımcıların bahsedilen durumda cep telefonlarını değiştireceklerine yönelik beyanlarının maddiyat konusuna bağlı olduğu göze ilişmektedir. Maddiyatın söz konusu olmadı̆̆ı durumlarda ise satın almanın gerçekleşebileceği kanısı hakimdir;

"Bir ünlü olsaydım, maddiyatım iyi olsaydı değiştirirdim tabii. Neden değģştirmeyeyim? (Z10)", "Paramla alakalı bir durum bu. Şu anki ekonomik durumumda düşünmem. Maddi kısıtlamam olmasa düşünebilirim tabii. (Z18)", "Ya şu şekilde düşünürüm. Param varsa, telefonum da eskimişse falan ama telefonum da idare ediyorsa gerek yok. İyi bir durumdaysam değiş̧tiririm tabii ki de. (Z21)"

Durumsal Değerle Ilgili Bulgular 
Araştırmadaki bir diğer tüketim değeri olan durumsal değer boyutu ile ilgili sorulan temel sorular ve katılımcıların verdikleri yanıtlar şu şekildedir:

Soru 1) Bazı dönemlerde ortaya çıkan fiyat indirimleri, telefon kampanyaları (eskiyi getir yeniyi götür, tarife ile birlikte satın alım, promosyon aksesuarlar vb.) gibi durumlar satın alma düşüncelerinizi etkiler mi?

Yanıtlar incelendiğinde eşit sayıda katılımcının bu soruya dair olumlu ve olumsuz görüş bildirdiği görülmektedir. Cevapların olumlu tarafındaki yanıtları içerisinde kampanya ve promosyonların çekiciliğinden bahsetmektedir;

"Evet, etkiliyor. Mesela yanında verilen promosyonlar ve indirimler insana daha çok sıcak gelen şeyler aslında. Kısacık bir kampanya, iki günlük kampanya olsa insan o zamana sığdırmaya çalışıyor alayım, yapayım edeyim (...). (Z7)", "Tabii değiştirir çünkü telefonu alıyorsam ve yanında bir şeyler hediye geliyorsa bir şeyleri daha fazla alabiliyorsam ayn fiyata tercih ederim yani. Bu beni mutlu eder (...). (Z11)"

Kampanya ve promosyonların katılımcılara yanıltıcı, yalan ve mantıksız gelmesi gibi sebepler ise cevapların olumsuz tarafını oluşturmaktadır. Kişiler duyduğu inançsızlıklar neticesinde kampanya ve promosyonları ciddiye almamakta, bu sebeple etkilenmediklerini dile getirmektedir;

"Hayır, asla hiçbir zaman etkilemedi, etkilemez de. Hatta o reklamları ciddiye falan da almıyorum. (Z1)", "Ben onlara inanmıyorum ya. (...) ben bunları pazarlama tekniği olarak görüyorum. (Z6)", "Etkilemez. Bunlar tamamen kapitalist sistemin oyunları bence. Yani mesela 100 dolara ürettikleri bir şeyi bize 1000 dolara satıyorlar, yanında kulaklı veriyorlar 5 dolarlık. Bu beni etkilemiyor doğrusu. (Z13)"

Soru 2) Satın almayı düşündüğünüz cep telefonu markasıyla ilgili olumlu veya olumsuz bir haber duymanız durumunda düşünceleriniz ne olur?

Büyük bir çoğunluğun satın alma davranışlarını değiştireceğini belirttiği bu soruda katılımcılar genelde bilgi kaynağını daha detaylı öğrenmek için araştırmalar yapacağını, haberin büyüklüğünün satın alma kararlarını etkileyeceğini ve doğruluğu kantlanmış çıkan haberlerde fikirlerinin değişebileceğini ifade etmektedir;

"Büyük bir haberse düşüncem değişir. Örneğin bu patlayan telefonlar vardı Samsung'un. Onu duyduktan sonra mesela Note serisine karşı bir önyargım oluştu. (Z14)", "Yani güvenilir bir şekilde gerçekten doğru bir haberse etkiler beni. Alacağım telefonu değiştirebilirim. (Z19)", "Illk önce bunun ciddi bir sorun olup olmadığını araştırırım sonra duruma göre değerlendiririm (...). (Z22)"

Soru 3) Cep telefonu satın alırken, satış görevlisinin tutumu ve size olan yaklaşımı satın alma tercihinizi etkiler mi?

Yapılan incelemeler doğrultusunda satış görevlilerin tutum ve davranışlarının Z Kuşağı tüketicilerinin üzerinde doğrudan etkisi olduğu açıkça belirtilebilir. Görünen odur ki Z Kuşağı bireyleri satış görevlilerinin davranışları konusunda oldukça hassas davranmaktadır. Gösterdikleri bu hassasiyet, davranışlar bağlamında hoşuna gitmedikleri zaman ileri dereceye varan olumsuz hislere dönüşüp bulundukları mağazadan satın alma kararından vazgeçireceği gibi tam tersi olumlu bir yaklaşımda da farklı bir ürünü satın almaya teşvik edecek kadar önemli bir konudur;

"Etkiler ama çok şey yaparsa çok şey olurum nasıl diyeyim sıkıntı basar diyeyim. Yani gittiğim zaman mağazaya çok fazla ilgilenilmesi beni rahatsı eder ama beni etkileyebilir de (...). (Z2)" "Tabii ki, çok fazla. Hatta ilk gittiğiniz anda telefon kötüyse dahi satış ve pazarlaması insanı olumlu yönde etkileyebiliyor. Aklında olmayan bir şeyi de alabiliyorsun. (Z7)", "Olur, değiş̧tirir. Yaşadım daha doğrusu. Turkcell'de telefon alacaktım. Adam o kadar tatlı konuşuyor ki ben ilk önce başka bir model almaya gitmiştim (...). Samimiyetine güvendim o anda adamın ondan dolayı aldım. (Z15)"

Soru 4) Cep telefonunuzun bozulması veya kırılması gibi önemli ve acil durumlarda telefon satın alma kararınızı neye göre verirsiniz?

Genel anlamda katılımcılar, telefonları kullanılamaz hale geldiği durumlarda aceleci bir tavır takınıp gelişigüzel satın alımlar gerçekleştirmek veya bilinçsizce davranışlar sergilemekten kaçınmaktadır. Eğer imkanları varsa mevcut telefonlarını tamir ettirme girişiminde bulunmakta veya bir şekilde kendilerini idare 
edebilecekleri eski model telefonlara yöneleceklerini belirtmektedir. Burada çok önemli bir nokta ise maddiyat konusudur. Maddiyat konusunun Z Kuşağının davranışları üzerinde büyük etkisi olduğu apaçık ortadadır;

"(...) eğer elimde yedek telefon yoksa da hemen almam telefonu. Önce birisinden bir telefon bulurum, düşünürüm o sırada ne alacağımı ya da maddi durumu falan. (Z6)", "Tamir ettirmeye çalışırım. Olmazsa geçici bir süreliğine o tamir olana kadar daha düşük özellikli bir telefon alırım (...). (Z13)", "Belki ailenin durumundan dolayı bir anda alınmayacak olabilir. Günü kurtaracak bir şekilde halledebilirim. Ondan sonra daha iyi bir model ya da daha iyi bir telefon almaya girişebilirim. Bir anda işte ben telefonumu kaybettim hemen gidip bir Iphone 11 alayım değil. (Z20)"

\section{Sonuç ve Tartışma}

Araştırma sonunda öne çıan ilk konu Z Kuşağı tüketicilerinin tüketim değerleri içerisinde en fazla önem verdiği boyutun fonksiyonel değer olduğu gerçeğidir. $Z$ Kuşağ 1 bireylerinin tamamı için cep telefonundaki fonksiyonel özellikler büyük önem taşımaktadır ve hatta birçoğu için cep telefonu satın alma sebeplerinin başında gelmektedir. Gümüş (2020) tarafından Z Kuşağının satın alma karar tarzlarının incelendiği çalışmasında Z Kuşağının kalite ve fiyat unsurlarını ön planda tutarak rasyonel tüketici davranışları sergilediği sonucuna ulaşmış olması da bu görüşü destekler niteliktedir. Başta cep telefonu kameralarının çözünürlük kalitesi olmak üzere kişisel beklentiler doğrultusunda fonksiyonel özelliklerin önemi ön plana çıkmaktadır. Sheth vd.'nin (1991) çalışmasında da fonksiyonel değerin tüketici satın alma tercihlerinde en güçlü uyaran olduğu belirtilmektedir. Bu durumun $\mathrm{Z}$ Kuşağı tüketicileri için de geçerli olduğu söylenebilir. Fonksiyonel özelliklerin büyük bir etken olduğu ortadayken katılımcıların verdiği yanıtlar doğrultusunda cep telefonunun kullanışlı özelliklere sahip olmasının tek başına yeterli olmadığını da belirtmek gerekmektedir.

Bir diğer boyut olan sosyal değer kapsamına bakıldığında Z Kuşağı tüketicilerinin satın alacakları üründe başkalarına tercihlerini beğendirme kaygılarının olmadığı, kendi beğenilerinin ön plana çıktığı görülmektedir. Mevcut kuşaklar içerisinde en fazla Z Kuşağının satın alma esnasında kendi bireysel beğenilerinin ön planda olduğunu belirten Sarı ve Harta'nın (2018) çalışması bu görüşü destekler niteliktedir. Yine katılımcılar, örnek aldıkları kişilere benzemek için kullandıkları üründen ziyade, karakter ve kişilik özelliklerine dikkat ettiklerini belirtmektedir. Ürün grubunun cep telefonu olmasının bu noktada önemli bir etken olduğu ifade edilebilir. Katılımcıların cep telefonu yerine diğer ürün gruplarında farklı yanıt vereceği, özellikle cep telefonuna kıyasla daha ucuz ve daha özendirici ürün gruplarında tam tersi yanıtlar alınacağı düşünülmektedir. Ayrıca, tüm katılımcılar satın alacakları cep telefonu hakkında çevrelerinden fikir toplayacaklarını beyan etseler de, bu fikirlerin yine kendi çıkarları doğrultusunda fonksiyonel özellikler temelinde ağır bastığı ifade edilmektedir. Tüm bu alınan yanıtlar doğrultusunda sosyal değerin düşük bulunduğu söylenebilir. Öte yandan Z Kuşağı, cep telefonlarının toplum içerisinde maddiyatı yansıtan bir araç olarak gördüklerini (özellikle Apple markası için) ama sosyal statü ile bir bağlantısı olmadığını, telefonların kişisel tercihler olduklarını düşündüklerini de belirtmek gerekmektedir.

Duygusal değer boyutunda ise Z Kuşağı tüketicilerinin satın alma esnasında duyguları yerine mantıklı davrandıkları görülmektedir. Bu kişiler mantık çerçevesinde cep telefonlarının fonksiyonel özelliklerini değerlendirerek satın alma kararlarını vermekte fakat direkt olarak duygularıyla hareket etmeseler de, düşük düzeyde bazı markaların kendilerine verdikleri güvenin etkisi olduğunu da belirtmektedirler. Kesin suretle satın almak için olumlu duyguların ve hissiyatların yeterli olmayacağını belirten katılımcılar, cep telefonunun kendilerini iyi hissettirmedikleri takdirde satın almayacaklarını da dile getirerek duygusal değer boyutunun satın alma tercihlerinde tam anlamıyla bağımsız olmadığını da ortaya koymaktadır.

Yenilik değerinde ise Z Kuşağının oldukça olumlu ve ilgili yanıtlar verdikleri görülmektedir. Bu sonuç, Z Kuşağı tüketicileri için beklenen bir durumdur. Yeni çıan cep telefonlarını incelemek, cep telefonlarında meydana gelen teknolojik gelişimlere merak duymak gibi davranış şekillerinin olduğu açıkla ortadadır. Fakat şu da özellikle belirtilmelidir ki; katılımcıların birçoğu kendilerine yeterli gördükleri cep telefonlarını kullandıklarında yeni bir telefon almaya girişmeyeceklerini beyan etmektedir. Birtakım katılımcılar da bu konudaki olumsuz cevaplarını maddiyat konusunda bağlamaktadır. Z Kuşağının maddi anlamda ailelerine bağımlı oldukları göz önüne alınırsa bu durum oldukça olağandır. Cep telefonu günümüzde pahalı bir ürün grubu olduğu için bu bağlamda satın alma durumlarının tam anlamıyla kişinin zevk ve ilgi düzeylerine göre gerçekleşemeyeceği de söylenebilir. Özetle, yenilik değerinin Z Kuşağı tüketim değerleri içerisinde güçlü bir etken olduğu belirtilebilir. 
Tüketim değerlerinin son boyutu olan durumsal değerin, Z Kuşağı tüketicilerinin dış etkenler tarafından birtakım uyaranlara maruz kaldıkları durumlarda ortaya çıktığı görülmektedir. Dış uyaranlar indirim, kampanya ve promosyonların gerçekçi, etkili ve samimi olduğu gibi durumlarda katılımcıların ilgisini çekip satın alma tercihlerine etkide bulunmaktadır. Yine dış etmenlerle bağlantılı olarak cep telefonları ile ilgili olumlu veya olumsuz haber duyduğu durumlarda, satın alma düşünceleri değişebilmektedir. Veya çevredeki etmenlerin diğer bir boyutu olan direkt üçüncü kişiler tarafından yani satış görevlilerinin hem olumlu hem olumsuz yönde doğrudan satın alma tercihine etkisi olduğu açıkça söylenebilir. Fakat hayatın doğal akışından kaynaklanan cep telefonlarının kullanılamaz hale geldiği durumlarda ise durumsal değerin bir etkisinin bulunmadığını söyleyebilmek mümkündür. Buradan hareketle satın alma durumlarının dış etmenlerden bağımsız olamayacağı düşünüldüğünde durumsal değerin $\mathrm{Z}$ Kuşağı üzerinde açıkça etkisi olduğu ifade edilebilir.

Sonuç olarak ortaya çıkan tabloda fonksiyonel, yenilik ve durumsal değerin Z Kuşağının tüketim değerlerini açıkça yansıttığı söylenebilir. Duygusal değerin fonksiyonel değere kısmen bağımlı olmasının yanı sıra sosyal değerin satın alma davranışı üzerinde etkisinin oldukça az görülmesinden kaynaklı bu çıkarımı yapmak mümkündür. Yine de duygusal veya sosyal boyutu tamamıyla soyutlayarak Z Kuşağının satın alma durumlarına hiçbir koşulda etkisi yoktur demek yanlış bir yaklaşım olacaktır.

Öte yandan birçok çalışmada olabileceği gibi bu çalışmada da araştırmanın birtakım kısıtları bulunmaktadır. En başta tüketim değerleri teorisinin uygulanabilmesi için bireylerin cep telefonuna sahip olması veya istediği marka/model telefonu kullanıyor olması gerekmektedir. Anakütleye erişmenin imkansızlığı dolayısı ile ortaya çıkan sınırlama ve ayrıca araştırmanın nitel bir çalışma olması dolayısı ile elde edilecek sonuçların evrenin tamamına genellenemeyecek olması en önemli kısıt olarak gösterilebilir. Öte yandan Z Kuşağı tüketicileri 2000 ve daha sonraki yıllarda doğan bireyleri ifade ettiğinden, bu kriter baz alınarak katılımcıların belirlenmesine yönelik yapılan ön görüşmeler neticesinde en küçüğü 2006 doğumlu bireyler çalışmaya dahil edilebilmiştir. Bu yıldan sonra doğan katılımcıların araştırmaya dahil olabilme uygunluğu bulunmadığı tespit edilmiştir ve ayrıca 2001 doğumlu katılımcılara ulaşılamamış olması da çalışmanın diğer kısıtlarıdır.

Araştırma, günümüz Z Kuşağının tüketim değerlerini cep telefonu ürünü üzerinden ortaya koymaktadır. Z Kuşağının gelişim psikolojisine göre ergenlik döneminde (Koç, 2004: 233) yer alıyor olmasından kaynaklı zaman içerisinde görüş ve fikirlerinin değişebileceği, ayrıca ailelerine maddi yönden bağımlı bir yaşam sürdükleri gerçeği göz önünde bulundurulmalıdır. Alınan yanıtlarda maddi konuların etkisi açıkça görülmektedir. İlerleyen dönemlerde benzer çalışmaların daha geniş çalışma gruplarıyla gerçekleştirilmesinin ve araştırmada birden fazla ürün grubuyla birlikte tüketim değerlerinin ele alınmasının literatüre daha fazla katkı sağlayacağı düşünülmektedir.

\section{Kaynakça}

Altıntaş, M. H. (2000). Tüketici Davranışları: Müssteri Tatmininden Müşteri Değerine. İstanbul: Alfa Yayınları.

Altuntuğ, N. (2012). Kuşaktan Kuşağa Tüketim Olgusu ve Geleceğin Tüketici Profili. Organizasyon ve Yönetim Bilimleri Dergisi, 4(1), 203-212.

Andrea, B., Gabriella, H.-C., ve Tímea, J. (2016). Y and Z Generations at Workplaces. Journal of Competitiveness, $8(3), 90-106$.

Arar, T., ve Yüksel, İ. (2015). Career Orientation for the New Generation of Turkish Human Resource. The Journal of Social Sciences Research, 1(5), 47-57.

Bejtkovský, J. (2016). The Current Generations: The Baby Boomers, X, Y and Z in the Context of Human Capital Management of the 21st Century in Selected Corporations in the Czech Republic. Littera Scripta, 9(2), 25-45.

Berkup, S. B. (2014). Working With Generations X And Y In Generation Z Period: Management Of Different Generations In Business Life. Mediterranean Journal of Social Sciences, 5(19), 218-229.

Bødker, M., Gimpel, G., ve Hedman, J. (2009). The User Experience of Smart Phones: A Consumption Values Approach. Global Mobility Roundtable, Kairo, Egypt. 
Ş. O. Çelebi - F. Bayrakdaroğlu 12/3 (2020) 3055-3070

Burucuoğlu, M. (2016). Tüketicilerin Etik Pozisyonu, Tüketim Değerleri ve Sorumlu Tüketim Davranışları Arasındaki İlişkiler Üzerine Bir Araştırma. Doktora Tezi. Samsun: Ondokuz Mayıs Üniversitesi

Candan, B., Ünal, S., ve Erciş, A. (2013). Analysing the Relationship Between Consumption Values and Brand Loyalty of Young People: A study on Personal Care Products. European Journal of Research on Education, $29-46$.

Chaney, D., Touzani, M., ve Slimane, K. B. (2017). Marketing to The (new) Generations: Summary and Perspectives. Journal of Strategic Marketing, 25(3), 179-189.

Chang, H.-S. (2008). Increase Hotel Customer Value by Reducing Relevant Perceived Risk in Taiwan. Journal of Hospitality \& Leisure Marketing, 16, 324-342.

Demir, A., Özkoç, H. H., ve Damgacı, U. (2017). Kuşakların Yaşam Memnuniyeti Açısından Farklılıklarının İncelenmesi. Içinde H. H. Özkoç ve F. Bayrakdaroğlu (Ed.), Kuşak Kavramına Disiplinler Arası Bakış. Ankara: Nobel Akademik Yayıncılık.

Dolot, A. (2018). The Characteristics of Generation Z. e-mentor, 44-50.

Erden Ayhün, S. (2013). Kuşaklar Arasındaki Farklılıklar ve Örgütsel Yansımaları. Muğla Sıtkı Koçman Üniversitesi İktisadi ve İdari Bilimler Fakültesi Ekonomi ve Yönetim Araştırmaları Dergisi, 2(1), 93-112.

Francis, T., ve Hoefel, F. (2018). 'True Gen': Generation $Z$ and its Implications for Companies. https://www.mckinsey.com/industries/consumer-packaged-goods/our-insights/true-gen-generationz-and-its-implications-for-companies

Gabbott, M., ve Hogg, G. (1998). Consumers and services. J. Wiley.

Gümüş, N. (2020). Z Kuşağı Tüketicilerin Satın Alma Karar Tarzlarının İncelenmesi. Journal of Yaşar University, 15(58), 381-396.

Khan, N. (2010). Functional and Relational Value Influence on Commitment and Future Intention: The Case of Banking Industry. The Journal of International Social Research, 3(10), 376-391.

Koç, M. (2004). Gelişim Psikolojisi Açısından Ergenlik Dönemi ve Genel Özellikleri. Erciyes Üniversitesi Sosyal Bilimler Enstitüsü Dergisi, 1(17), 231-238.

Latif, H., ve Serbest, S. (2014). Türkiye'de 2000 Kuşağı ve 2000 Kuşağının İş ve Çalışma Anlayışı. Gençlik Araştırmaları Dergisi, 2(4), 134-163.

Marangoz, M., ve Aydın, A. E. (2017). Pazarlama Yönetiminde Pazarlar. Içinde M. Marangoz (Ed.), Pazarlama Yönetimi. İstanbul: Beta Yayıncilik.

Odabaşı, Y. ve Barış, G. (2007). Tüketici Davranışı. İstanbul: MediaCat Kitapları.

Özkan, M., ve Solmaz, B. (2017). Generation Z - The Global Market's New Consumers- And Their Consumption Habits: Generation Z Consumption Scale. European Journal of Multidisciplinary Studies, 2(5), 150-157.

Patel, D. (2017). 8 Ways Generation Z Will Differ From Millennials In The Workplace. https://www.forbes.com/sites/deeppatel/2017/09/21/8-ways-generation-z-will-differ-frommillennials-in-the-workplace/\#1d357ca476e5

Sánchez Fernández, R., ve Iniesta Bonillo, M. Á. (2007). The Concept of Perceived Value: A Systematic Review of the Research. Marketing Theory, 7(4), 427-451.

Sarı, E., ve Harta, G. (2018). Kuşakların Tüketim ve Satın Alma Davranışları Üzerine Bir Araştırma. Uluslararası Sosyal Araştırmalar Dergisi, 11(61), 967-980.

Sheth, J. N., Newman, B. I., ve Gross, B. L. (1991). Why we buy what we buy: A theory of consumption values. Journal of Business Research, 22(2), 159-170. https://doi.org/10.1016/0148-2963(91)90050-8

Strauss, W., ve Howe, N. (1991). Generations: The history of America's future, 1584 to 2069. William Morrow and Company Inc. 
Ş. O. Çelebi - F. Bayrakdaroğlu 12/3 (2020) 3055-3070

Tek, Ö. B. (2006). Pazarlamada Değer Yaratmak. İstanbul: Hayat Yayıncılık.

Tuncer, U. M. (2016). A ̆̆ Toplumunun Çocukları: Z Kuşağının Kişilerarası İletişim Becerilerinin Çok Boyutlu Analizi. Atatürk İletişim Dergisi, 10, 33-46.

Turel, O., Serenko, A., ve Bontis, N. (2010). User Acceptance of Hedonic Digital Artifacts: A Theory of Consumption Values Perspective. Information \& Management, 47(1), 53-59.

Türnüklü, A. (2000). Eğitimbilim Araştırmalarında Etkin Olarak Kullanılabilecek Nitel BirAraştırma Tekniği: Görüşme. Kuram ve Uygulamada Ĕ̆itim Yönetimi, 24(24), 543-559.

Williams, K. C., ve Page, R. A. (2011). Marketing to the Generations. Journal of Behavioral Studies in Business, 3, $1-17$.

Yaşin, B. (2007). Tüketicilerin Alışveriş Stilleri ile Tüketim Değerleri Arasındaki İlişkinin Belirlenmesine Yönelik Bir Araştırma. Doktora Tezi. İstanbul: İstanbul Üniversitesi

Yıldırım, S. (2013). Tüketicilerin Kişisel Değerleri ile Tüketim Değerleri Arasındaki İlişkinin İncelenmesi (Çevre Dostu Ürün Kullanan Tüketiciler Üzerine Bir Araştırma). Doktora Tezi. Kocaeli: Kocaeli Üniversitesi 